\title{
ANALISIS FILOGENETIK KERBAU LOKAL LOMBOK TENGAH (Bubalus bubalis) BERDASARKAN PENANDA DNA MIKROSATELIT
}

\author{
Akhmad Sukri \\ IKIP Mataram \\ sukri_bio04@yahoo.co.id \\ Diterima 26 September 2014 disetujui 9 November 2014
}

\begin{abstract}
This study examines the phylogenetic relationships of two populations of Central Lombok local buffalo (Bubalus bubalis) through microsatellite DNA markers based on three random primers, namely HEL09, INRA 023 and INRA 032. Grouping several individual buffalo from the two populations into one cluster showed genetic mixing. The existence of genetic mixing allegedly because the buffalo population is spread open local population. Many buffalo imported from other populations in Central Lombok district or from other areas by farmers to be maintained along with buffalos that already exist, resulting in mixing or close relatives outside marriage among individual local buffalo of Central Lombok.
\end{abstract}

Keywords : phylogenetic analysis, Bubalus bubalis, microsatellite

\section{PENDAHULUAN}

Jenis kerbau di dunia dibagi menjadi dua, yaitu kerbau Asia (Bubalus bubalis) dan kerbauAfrika (Syncerus caffer). Kerbau Asia terbagi kedalam dua subspesies, yaitu kerbau sungai (river buffalo) dan kerbau lumpur (swamp buffalo) (Lanuzzi dan Di Meo, 2009). Kerbau sungai banyak digunakan sebagai penghasil susu dan penghasil daging, sedangkan kerbau lumpur utamanya digunakan sebagai alat transportasi selain sebagai penghasil daging (Aziz, 2008). Sebagian besar kerbau lokal Indonesia adalah kerbau lumpur (sekitar 98\%), dan sisanya dalam jumlah kecil (sekitar 2\%) adalah kerbau sungai (Erdiansyah \& Anggraeni, 2008). Kerbau lumpur (Bubalus bubalis) mempunyai variasi pada bobot badan dan warna kulit, sehingga di Indonesia kerbau lumpur dikenal dengan berbagai nama, seperti kerbau Jawa, Aceh, Toraja, Kalang dan Moa (Triwulaningsih, 2008).

Propinsi Nusa Tenggara Barat merupakan salah satu wilayah yang memiliki populasi kerbau terbanyak di Indonesia dimana pada tahun 2012 menempati posisi ketiga secara nasional dengan jumlah populasi kerbau sebesar 144.232 ekor (Ditjennak, 2014). Kabupaten
Lombok Tengah merupakan salah satu pensuplai ternak kerbau di Propinsi Nusa Tenggara Barat yang memiliki jumlah populasi kerbau tertinggi di Pulau Lombok pada tahun 2012, yaitu sebesar 18.894 ekor (Disnakkeswan NTB, 2014). Kabupaten Lombok Tengah memiliki potensi pengembangan ternak kerbau yang cukup besar yang ditunjang oleh daya dukung lingkungan dan kondisi sosial budaya. Hilmiati (2008) mengungkapkan bahwa lahan di Nusa Tenggara Barat mampu mendukung sekitar 2,6 juta satuan ternak baik untuk ternak besar dan kecil termasuk di dalamnya lahan peternakan kerbau di Kabupaten Lombok Tengah. Kondisi sosial budaya mendukung pengembangan peternakan kerbau di Lombok Tengah. Pada sebagian masyarakat Lombok Utara dan Lombok Tengah, upacara perkawinan dengan pemotongan kerbau dianggap suatu prestise tersendiri (Sukri et al, 2012).

Besarnya jumlah populasi dan potensi pengembangan ternak kerbau di Kabupaten Lombok Tengah perlu diikuti oleh upaya konservasi plasma nutfah kerbau melalui inventariasasi sumber daya genetik. Hal ini dilakukan sebagai upaya perlindungan sumber daya genetik kerbau untuk keperluan mendatang. Salah satu 
cara untuk melakukan inventarisasi sumber daya genetik kerbau dilakukan melalui analisis filogenetik. Penelitian ini mengkaji hubungan filogenetik populasi kerbau lokal Lombok Tengah melalui penanda DNA mikrosatelit.

\section{METODE}

\section{Sampel Darah dan Isolasi DNA}

Sampel darah diambil dari 15 individu kerbau lokal Lombok Tengah pada dua populasi berbeda. Darah diambil melalui vena jugularis di leher menggunakan venoject dan tabung vacum (kosong). Tabung yang berisi darah kemudian diberi EDTA sebanyak 0,1 gr agar darah tidak membeku. Darah kemudian disimpan di dalam lemari es sampai proses isolasi DNA dilakukan. Proses isolasi DNA dilakukan menggunakan KIT Nucleospin ${ }^{R}$ Quickpure Blood. Untuk mendeteksi DNA hasil isolasi digunakan elektroforesis gel agarose $0,8 \%$.

\section{Analisis Mikrosatelit}

Penelitian ini menggunakan tiga primer mikrosatelit yang dipilih secara acak yaitu HEL09, INRA 023, dan INRA 032. Proses amplifikasi DNA melalui Polimerase Chain Reaction (PCR) terdiri dari campuran reaksi 2,5 $\mu 1$ DNA template, 2,5 $\mu$ l primer forward, $2,5 \mu$ l primer reverse,

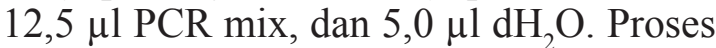
PCR terdiri dari 30 siklus dengan tahapantahapan sebagai berikut: predenaturasi pada suhu $95^{\circ} \mathrm{C}$ selama 2 menit, denaturasi pada suhu $92^{\circ} \mathrm{C}$ selama 1 menit, annealing pada suhu $56^{\circ} \mathrm{C}$ selama 45 detik, elongation pertama pada suhu $72^{\circ} \mathrm{C}$ selama 1 menit, final elongation pada suhu $72^{\circ} \mathrm{C}$ selama 10 menit, dan tahap terakhir pada suhu $4^{\circ} \mathrm{C}$.

\section{Analisis Data}

Proses separasi DNA hasil PCR, dilakukan menggunakan elektroforesis gel poliakrilamid yang dilanjutkan dengan pewarnaan perak (silver staining). Penentuan posisi pita atau alel DNA pada gel poliakrilamid dilakukan secara manual. Ukuran dan jumlah alel yang muncul pada gel ditentukan berdasarkan asumsi bahwa semua pita DNA dengan laju migrasi yang sama adalah homolog (Leung et al, 1993). Seluruh alel yang muncul dicatat kemudian dirubah kedalam bentuk data biner, yaitu dengan melihat ada tidaknya pita atau alel mikrosatelit pada ukuran tertentu. Rekonstruksi pohon filogenetik dilakukan berdasarkan data biner yang dibantu dengan program komputer Multi Variat Statistical Package (MVSP) versi 3.1.

\section{HASIL}

Salah satu hasil amplifikasi DNA mikrosatelit kerbau lokal Lombok Tengah (Bubalus bubalis) menggunakan primer Hel09 ditampilkan pada Gambar 1 dan 2 berikut.

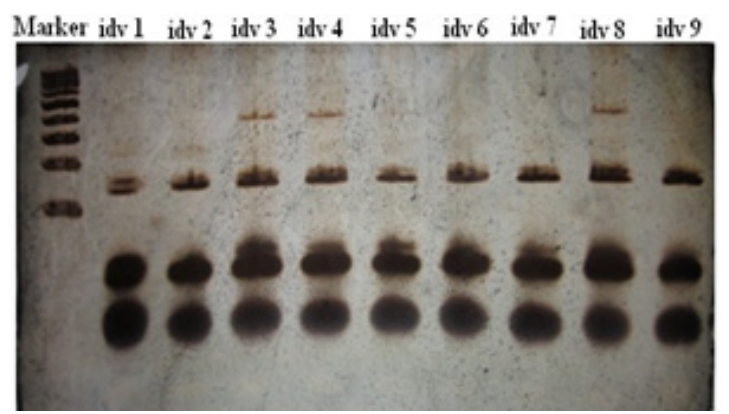

Gambar 1. Tampilan Alel-alel DNA Mikrosatelit Menggunakan Primer HEL09 pada Individu 1-9 Kerbau Lokal Lombok Tengah.

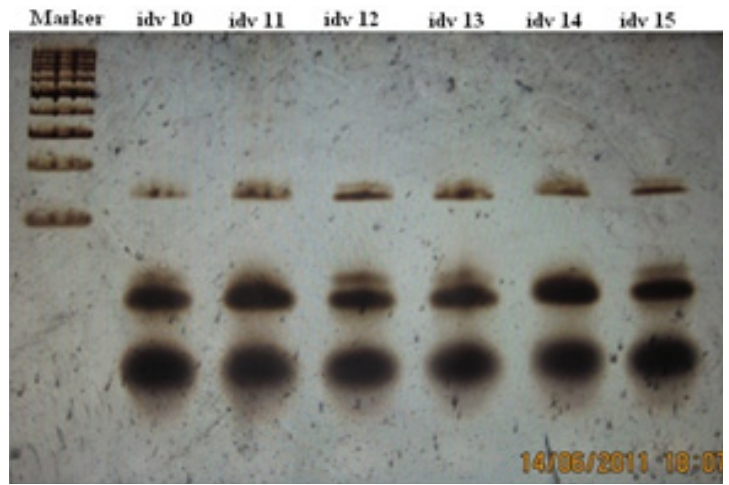

Gambar 2 Tampilan Alel-alel DNA Mikrosatelit Menggunakan Primer HEL09 pada Individu 10-15 Kerbau Lokal Lombok Tengah.

Hasil konversi data alel mikrosatelit menjadi data biner berdasarkan 3 primer acak ditampilkan pada Tabel 1 berikut. 
Tabel1. Konversi Alel DNA Mikrosatelit Menjadi Data Biner Berdasarkan 3 Primer, yaitu HEL09, INRA 023, dan INRA 032

\begin{tabular}{cccccc}
\hline Individu & \multicolumn{5}{c}{ Lokus Bp } \\
\cline { 2 - 6 } & $\mathbf{1 5 0}$ & $\mathbf{2 0 0}$ & $\mathbf{2 2 0}$ & $\mathbf{3 0 0}$ & $\mathbf{4 0 0}$ \\
\hline 1 & 1 & 1 & 1 & 1 & 0 \\
2 & 1 & 1 & 1 & 0 & 0 \\
3 & 1 & 1 & 1 & 1 & 1 \\
4 & 1 & 1 & 1 & 1 & 1 \\
5 & 1 & 1 & 1 & 0 & 0 \\
6 & 1 & 1 & 1 & 1 & 0 \\
7 & 1 & 1 & 1 & 1 & 0 \\
8 & 1 & 1 & 1 & 1 & 1 \\
9 & 1 & 1 & 1 & 0 & 0 \\
10 & 1 & 1 & 1 & 1 & 0 \\
11 & 1 & 0 & 1 & 0 & 0 \\
12 & 1 & 1 & 1 & 1 & 0 \\
13 & 1 & 1 & 1 & 1 & 0 \\
14 & 1 & 1 & 1 & 1 & 0 \\
15 & 1 & 1 & 1 & 1 & 0 \\
\hline
\end{tabular}

Keterangan:

(1): ada pita DNA,

(2): tidak ada pita DNA

Hasil analisis filogenetik kerbau lokal Lombok Tengah berdasarkan 3 primer acak ditampilkan pada Gambar 3.

\section{PEMBAHASAN}

Hasil analisis filogenetik yang ditampilkan pada Gambar 3 menunjukkan posisi taksonomi kerbau lokal Lombok Tengah dari dua populasi yang berbeda. Populasi pertama diwakili oleh individu 1 sampai individu 7, sedangkan untuk populasi kedua diwakili oleh individu 8 sampai individu 15 (Gambar 1 dan 2).

Pohon filogenetik (Gambar 3) menunjukkan adanya pengelompokkan individu kerbau dari dua populasi menjadi tiga group utama. Kelompok pertama meliputi individu kerbau 1, 6, 7, 10, 12, 13, 14, dan 15. Individu 10 sampai individu 15 merupakan kerbau dari populasi kedua, sedangkan individu 1, 6, dan 7 merupakan kerbau dari populasi pertama.
Pengelompokkan individu kerbau dari populasi pertama dan kedua menjadi satu cluster menunjukkan adanya hubungan kekerabatan diantara individu kerbau tersebut. Hal ini diduga karena terjadinya perkawinan diantara populasi kerbau tersebut yang dilakukan oleh peternak melalui perdagangan, sehingga terjadi percampuran genetik diantara individu kerbau dari kedua populasi.

Pola yang sama juga dapat diamati pada kelompok kedua dan ketiga pohon filogenetik kerbau lokal Lombok Tengah (Gambar 3). Pada kelompok kedua (individu 2, 5, dan 9) dan ketiga (individu 3,4 , dan 8) individu dari populasi pertama dan kedua bergabung menjadi satu cluster. Hal ini juga mengindikasikan adanya percampuran genetik diantara individu dari dua populasi sampling.

Hasil yang diperoleh memperkuat dugaan dari penelitian sebelumnya yang dilakukan oleh Sukri et al (2012) yang melihat keanekaragaman genetik diantara dua populasi kerbau Lombok Tengah berdasarkan penanda mikrosatelit. Hasil penelitian tersebut mengungkapkan nilai observed heterozygosity lebih tinggi dibandingkan dengan nilai expected heterozygosity yang mengindikasikan kelebihan heterozigositas pada kedua populasi kerbau Lombok Tengah, artinya perbedaan genetik diantara populasi yang dibandingkan tinggi.

$$
\text { El-Kholy et. al., }
$$
mengungkapkan heterozigositas genetik yang tinggi memperkirakan adanya generasi campuran yaitu populasi campuran dari area-area yang berbeda, aliran gen, dan seleksi alami. Hal ini dibuktikan melalui rekonstruksi pohon filogenetik kerbau lokal Lombok Tengah yang mengindikasikan adanya percampuran genetik diantara individu dari dua populasi (Gambar 3).

Satu dugaan kuat yang mengakibatkan adanya percampuran genetik diantara kedua populasi kerbau lokal Lombok karena kedua populasi kerbau yang ada merupakan populasi lokal yang penyebarannya terbuka, artinya banyak individu kerbau yang didatangkan dari populasi lain di Kabupaten Lombok 
Tengah atau dari daerah lain oleh para peternak untuk dipelihara bersamaan dengan individu-individu kerbau yang sudah ada, sehingga terjadi percampuran atau perkawinan diluar kerabat dekat diantara individu kerbau.

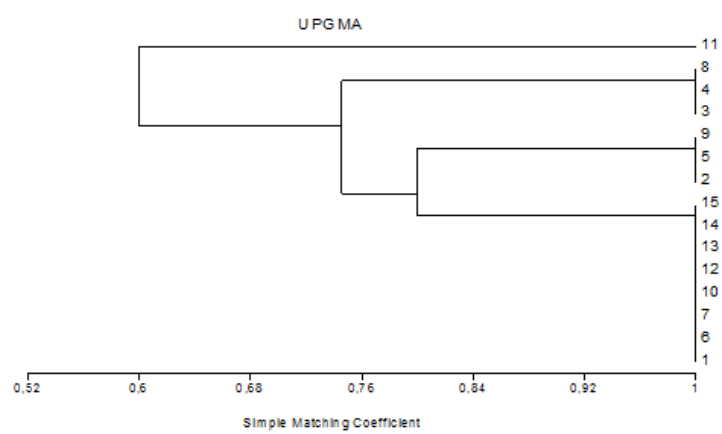

Gambar 3. Rekonstruksi Pohon Filogenetik Kerbau Lokal Lombok Tengah Berdasarkan Metode UPGMA (Unweighted Pair Group with Mean Arithmatic Method).

\section{DAFTAR PUSTAKA}

Aziz, M.M. 2008. Nili Ravi Buffalopotential and challenges. BRI Bulletin Quarterly. Vol 01 (01): 1.

Disnakkeswan NTB. 2014. Perkembangan Populasi Ternak (2008 s/d 2012), (online),(http://disnakkeswan. ntbprovgo.id, diakses tanggal $10 \mathrm{Juli}$ 2014).

Ditjennak. 2014. Populasi Nasional Ternak Kerbau Tahun 2008 s/d 2013, (online),(http://ditjennak.deptan. go.id, diakses tanggal 01 Juni 2014).

Erdiansyah, E dan Anggraeni, A. 2008. Keragaman Fenotipe dan Pendugaan Jarak Genetik antara Subpopulasi Kerbau Rawa Lokal di Kabupaten Dompu, Nusa Tenggara Barat, Prosiding Seminar dan Lokakarya Nasional Usaha Ternak Kerbau, Tana Toraja: 24-26 Oktober.

El-Kholy, A.F.,Hassan, H.Z.,Amin, A.M.S. \& Hassanance, M.S. 2007. Genetic diversity in Egyptian buffalo using microsatellite markers. Arab J. Biotech, Vol 10 (2) : 219-232.

Hilmiati, N. 2008. Potensi Kerbau Sebagai Substitusi Daging Sapi di Nusa Tenggara Barat, (Online), (http:// www.ntb.litbang.deptan.go.id/index. php?, diakses tanggal 10 Maret 2010).

Lanuzzi, L \& Di Meo, G.P. 2009. Genome Mapping and Genomics in Domestic Animals. United State of America: Springer-Verlag Berlin Heidelberg.

Leung, H.,Nelson, R.J \& Leach, J.E. 1993. Population structure of plant pathogenic fungi and bacteria, Plant Pathol, Vol 10: 157-205.

Sukri, A.,Amin, M.,Winaya, A \& Maslikah, S.I. 2012. Variasi Genetik Kerbau Lokal (Bubalus bubalis) Lombok Tengah, Nusa Tenggara Barat Berbasis Mikrosatelit, Prosiding Seminar Nasional MIPA dan Pembelajaran: Peran MIPA dan Pembelajaran Menuju Revitalisasi Karakter Bangsa di Era Globalisasi, Malang: 13 Oktober.

Triwulaningsih, E. 2008. Kerbau Sumber Daging dan Susu, Mungkinkah?, (Online), (http://www.pustakadeptan.go.id/publikasi-wr274055. pdf, diakses 10 Maret 2010). 